\title{
Enhanced silk performance by enriching the silkworm diet with bordeaux mixture
}

\author{
J. Fernandes ${ }^{1}$, D. Nicodemo ${ }^{1, *}$ (1), J. E. Oliveira ${ }^{2}$, F. A. Silva ${ }^{3}$, M. E. A. Fidelis ${ }^{4}$, L. E. Silva ${ }^{5}$,
} and G. H. D. Tonoli ${ }^{5}$

${ }^{1}$ Faculdade de Ciências Agrárias e Tecnológicas, Universidade Estadual Paulista, Campus de Dracena, Rod. Comandante João Ribeiro de Barros, Km 651, CEP 17900-000 Dracena, SP, Brazil

${ }^{2}$ Departamento de Engenharia, Universidade Federal de Lavras, Campus Universitário, Lavras, MG CEP 37200-000, Brazil

${ }^{3}$ Department of Civil Engineering, Pontifícia Universidade Católica do Rio de Janeiro (PUC-Rio), Rua Marquês de São Vicente 225,

Rio de Janeiro, RJ 22453-900, Brazil

${ }^{4}$ Departamento de Engenharia Civil, COPPE/Universidade Federal do Rio de Janeiro, Centro de Tecnologia, Bloco I- Sala 216,

Caixa Postal 68506, Rio de Janeiro, RJ 21941-972, Brazil

${ }^{5}$ Departamento de Ciências Florestais, Universidade Federal de Lavras, Campus Universitário, Caixa Postal 3037, Lavras,

MG CEP 37200-000, Brazil

Received: 19 August 2016

Accepted: 2 November 2016

Published online:

8 November 2016

(C) Springer Science+Business

Media New York 2016

\section{ABSTRACT}

This work evaluated the effect of different concentrations $(5,10$, and 20\%) of Bordeaux mixture $(\mathrm{Bm})$ in the diet of the silkworm caterpillars in order to improve the cocoon production and structural and mechanical properties of the ensuing silk. The cocoon yield, tensile properties, and microstructure (X-ray diffraction, surface fracture, and qualitative composition) of the obtained silk fiber threads were determined. The mortality levels of caterpillars fed on mulberry leaves with $\mathrm{Bm}$ were up to $80 \%$ higher than the rates observed on caterpillars fed on non-treated leaves. The consumption of leaves decreased as the amount of Bm introduced to the caterpillars' diets was increased. However, the lower demand of leaves by caterpillars fed on leaves treated with 5 and $10 \%$ of Bm did not imply in obtaining lower cocoon productivity, as the raw silk rates were not different in comparison to the control group. The tensile strength and maximum strain of the fiber were greatly improved, whereas the toughness was not statistically improved by the presence of $\mathrm{Bm}$ in the diet. There was an increase in the concentration of $\mathrm{Ca}$ and $\mathrm{Cu}$ in the silk fiber threads treated with $\mathrm{Bm}$, leading to higher crystallinity. If the cocoon producers were rewarded with an increase in cocoon quality, the application of Bm could be interesting, despite the increase in caterpillars' mortality.

Address correspondence to E-mail: nicodemo@dracena.unesp.br 


\section{Introduction}

Sericulture is an important agro-industrial activity that can generate great income in areas with less than $10 \mathrm{ha}$, as well as the rationalization of the family labor [1]. Brazil is the fourth largest producer of green cocoons and silk fibers, with $97 \%$ of its production being destined to exportation [2]. The excellent quality of Brazilian silk attracts the international market, which aims the production of sophisticated fabrics of high added value, indicating the great potential of production of cocoons in Brazil. There is a rigorous selection of the cocoons produced and just those of first quality enter the production line of the best quality fiber [3]. Silk of high quality can also be used as an interesting biomaterial with biomedical or biotechnological purposes [4-6].

The silkworm (Bombyx mori) feeds exclusively from the leaves of the mulberry (Morus spp.) where it gets water and the necessary nutrients for development. The need of fresh food is a vulnerable condition for the silkworm that affects the quality of the silk fiber. Thus, even showing features that normally meet the basic needs, the mulberry tree is the cause of significant changes in the silk composition. These are related to the variables on cultivation processes: climatic conditions, spacing of cultivation, water availability, soil types, pruning, leaf growth and maturity, transport and storage of the leaves, among others [7]. The mulberry leaf is composed primarily of water, proteins, carbohydrates, vitamins, sterols, and minerals. The caterpillars of silkworm obtain the nutrients from the mulberry leaves to build up the body, sustain life, form cocoons, and reproduce [2, 8]. Meeting nutritional requirements through food consumption has a direct impact on the gene expression of characteristics such as weight of the caterpillar and the cocoon, quantity and quality of the silk, and reproductive characteristics of moths [9].

The nutrition of the silkworm refers to nutrients required for the caterpillars to their growth and development of metabolic functions that enable the protein synthesis through various biochemical pathways, including silk protein fiber and determining the quantity and quality of silk fiber thread produced by caterpillars [10-12]. However, little information is available about the requirements for specific substances, qualitatively and/or quantitatively, that allow the growing of silkworm and their normal development.
Qualitative changes in food also produce differences in the quantity and quality of the silk produced. It is therefore of fundamental importance to study and evaluate the nutritional increment of caterpillars by enriching mulberry leaves, with a focus on increasing the production and quality of cocoons. On studying [13] the role of $\mathrm{Cu}$ in the formation process of silk, it was stated that there is evidence that the copper ions interact with the silk fibroin, starting the transition of the protein tertiary structure. There is great evidence that the excellent properties presented by the silk fiber are heavily more dependent on this process of protein formation than on the protein sequence of the structure of the silk fiber thread. The authors also claim that the fibroin of silk contains several amino acids having free $\mathrm{NH}_{2}$ and $\mathrm{OH}$ groups, such as histidine, lysine, tyrosine, and sericin. Similarly to observed for spider silk, its higher toughness is majorly due to a complex "coat-skin-core" with formation of microfibrils structures and the alignment of the silk [14]. Therefore, it is reasonable to assume that $\mathrm{Cu}$ could form a complex with the macromolecules of fibroin, and with the histidine residues and glycine. Furthermore, the $\mathrm{Cu}$ diet lead to structures being more resilient and cohesive during the formation of the silk thread. This mechanism suggests that higher concentrations of $\mathrm{Cu}$ in the diet increase the silk tensile strength through conformational changes. Similarly, $\mathrm{TiO}_{2}$ nanoparticles in the artificial diet of the silkworms also led to direct production of intrinsically modified silk, increasing the strength and toughness of the silk [15].

The Bordeaux mixture $(\mathrm{Bm})$ is a traditional agricultural fungicide composed of $\mathrm{Cu}$ sulfate and hydrated lime in a simple mixture. It has proven to be more efficient over several fungal diseases, especially infections caused by Plasmopara viticola. It also presents fungicide action against infections by bacteria and certain pests. Researchers [16] achieved satisfactory results in reducing the incidence of diseases in grapevines like Goethe, by applying a dose of $0.4 \%$ of $\mathrm{Bm}$. Considering that the Bordeaux mixture consists of the mixture of lime and $\mathrm{Cu}$ sulfate in aqueous solution, it is suggested that its use in sericulture can encourage silkworm rearing, with the purpose of preventing the development of fungal and viral diseases and increase the quality of silk fiber threads produced by caterpillars.

The objective of this study was to evaluate whether the addition of $\mathrm{Bm}$ in the diet of the silkworm larva 
(a)

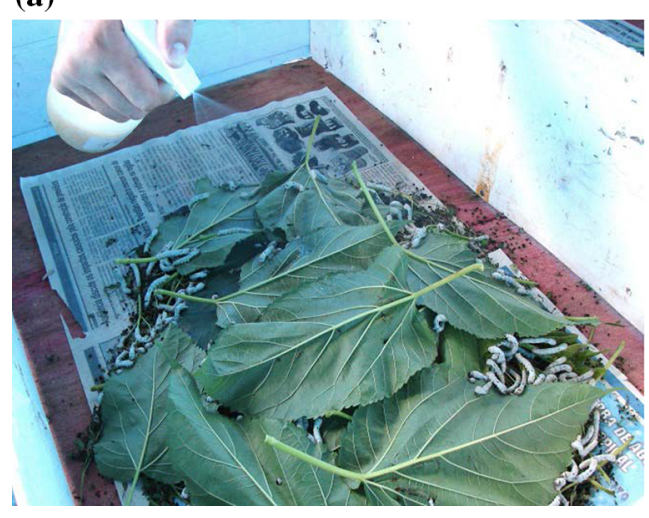

(b)

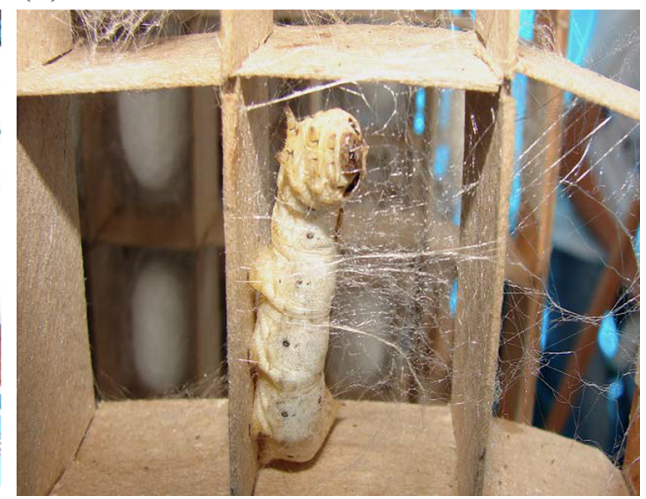

Figure 1 a Application of an aqueous solution with Bordeaux mixture $(\mathrm{Bm})$ in mulberry leaves offered to the silkworm caterpillars in 4th instar; $\mathbf{b}$ caterpillar starting to weave a cocoon.

Table 1 Average amount of mulberry leaves $(\mathrm{mg})$, water $(\mu \mathrm{L})$, and Bordeaux mixture$\mathrm{Bm}(\mu \mathrm{L})$ offered for each silkworm caterpillar in the third, fourth, and fifth stages

\begin{tabular}{|c|c|c|c|c|c|c|c|c|c|}
\hline \multirow[t]{2}{*}{ Diets } & \multicolumn{3}{|c|}{ 3rd instar } & \multicolumn{3}{|c|}{ 4th instar } & \multicolumn{3}{|c|}{ 5th instar } \\
\hline & Leaves & Water & $\mathrm{Bm}$ & Leaves & Water & $\mathrm{Bm}$ & Leaves & Water & $\mathrm{Bm}$ \\
\hline Control & 637 & - & - & 2333 & - & - & 18,030 & - & - \\
\hline Water & 637 & 77.8 & - & 2333 & 155.6 & - & 18,030 & 744.5 & - \\
\hline $\mathrm{Bm} 5 \%$ & 637 & 73.9 & 3.9 & 2333 & 147.8 & 7.8 & 18,030 & 707.2 & 37.2 \\
\hline $\mathrm{Bm} \mathrm{10 \%}$ & 637 & 70.0 & 7.8 & 2333 & 140.0 & 15.6 & 18,030 & 670.0 & 74.5 \\
\hline $\mathrm{Bm} 20 \%$ & 637 & 62.2 & 15.6 & 2333 & 124.5 & 31.1 & 18,030 & 595.6 & 148.9 \\
\hline
\end{tabular}

improves the cocoon production and the structural and mechanical properties of the ensuing silk.

\section{Methodology}

\section{Silk production and treatments}

The silkworm rearing was performed in Dracena, São Paulo state, Brazil, which is located at latitude $21^{\circ} 27^{\prime} 37^{\prime \prime} \mathrm{S}$ and longitude $51^{\circ} 33^{\prime} 21^{\prime \prime} \mathrm{O}$, and has an altitude of $421 \mathrm{~m}$. The caterpillars have remained in plywood rearing beds $-1 \mathrm{~m}$ wide, $3 \mathrm{~m}$ long, and $50 \mathrm{~cm}$ height-which were allocated on a rearing shed with controlled temperature $\left(\sim 27^{\circ} \mathrm{C}\right)$ and controlled relative humidity $(\mathrm{RH}=70 \%)$. They were fed on mulberry (Morus spp. FM86 cultivar) leaves. The harvest of the mulberry leaves was held daily in the early morning and late afternoon. Before each feeding period, the leaves were removed from stems, weighed, submitted to the treatment with solutions, and offered equally to the caterpillars of the respective treatments. The amount of leaves provided along the caterpillars rearing was adjusted in relation to the consumption of leaves, growing gradually until the end of the last instar [2].

The caterpillars were divided and subjected to five treatments, each one consisting of around 1500 caterpillars, subdivided into repetitions with 500 caterpillars in the beginning of the third larval instar. They were fed with mulberry leaves in four daily treatment sessions ( $7 \mathrm{~h} 30 \mathrm{am}, 11 \mathrm{~h} 30 \mathrm{am}, 3 \mathrm{~h} 30 \mathrm{pm}$, and $7 \mathrm{~h} 30 \mathrm{pm}$ ).

Five experimental diets were established, with the amount of mulberry leaves being equal between the groups. The diet 1 (control) contained only mulberry leaves. The diet 2 was composed of mulberry leaves moistened with water. The diets 3,4 , and 5 have been added to an aqueous solution with 5,10 , and $20 \%$ of $\mathrm{Bm}$, respectively (Fig. 1a). The amount of leaves, water, and $\mathrm{Bm}$ used in feeding of the caterpillars is described in Table 1.

Food consumption was verified at the end of the third, fourth, and fifth stages of development of the caterpillars by placing a plastic net over the bed. The larvae passed through the plastic net to feed on fresh leaves; then the leaves that were below the net were removed and quantified [17]. 
(a)

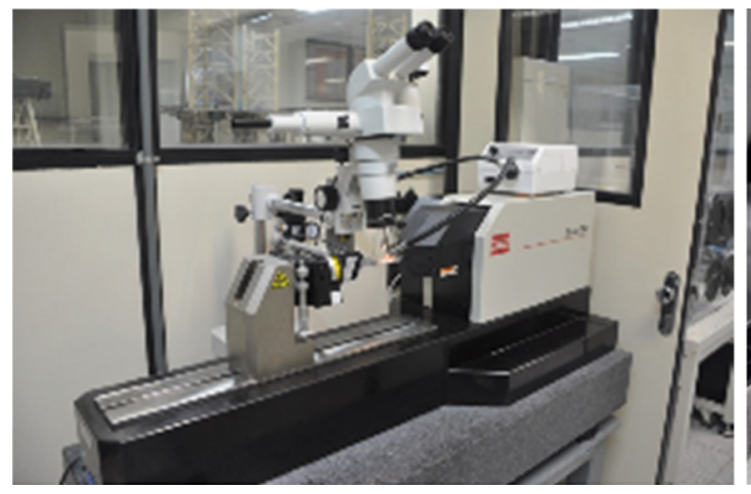

(b)

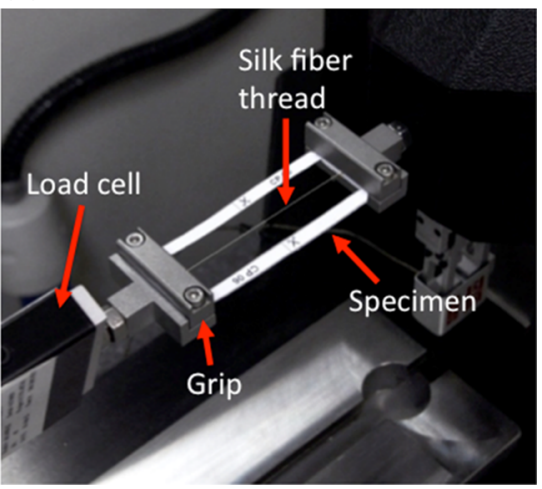

Figure 2 The tensile test system: a overall view of the microtesting machine coupled with a stereomicroscope. The microscope was used to check the silk fiber alignment and possible defects in the silk fiber thread; $\mathbf{b}$ detail of clamps and specimen.

At the end of the feeding period of the caterpillars, the management for cocooning was held by the placement of a wood structure over the rearing site and subsequent elevation so that the caterpillars could weave the cocoons. The harvest took place on the eighth day after the formation of the first pod (Fig. 1b).

All cocoons were weighted, with the exception of those that presented defects, determining the weight of fresh cocoons. Then, the cocoons were cut for the removal of pupae and spoils, and weighed again in order to obtain the weight of cocoon shells. Then, with these data, the raw silk content was calculated. Cocoons were oven-dried at $60{ }^{\circ} \mathrm{C}$ for 3 days. Then, in order to obtain individual silk threads, cocoons weaved by caterpillars from the same treatment were placed in a pan with boiling water for $30 \mathrm{~min}$. The first $10 \mathrm{~m}$ of silk from each cocoon was discarded.

\section{Tensile test of the silk threads}

The silk threads were tested, in a natural dry condition, under tensile loading at a gage length (GL) of $20 \mathrm{~mm}$. Fifteen tests were carried out for each treatment, on a micro-force testing system (Tytron 250, MTS Systems, Minneapolis. MN, USA., see Fig. 2). A steel flat-shaped mechanical clamp was used to hold the fibers. The preparation of the specimen was performed according to ASTM C1557 [18]. A $25 \mathrm{~N}$ load cell was used to measure the load. The displacement of the fiber was measured using a short-stroke transducer with a resolution of about $0.1 \mu \mathrm{m}$. Tensile tests were conducted in displacement control at a rate of $0.5 \mathrm{~mm} / \mathrm{min}$. This displacement rate corresponded to a nominal strain rate, in the linear region of the stress-strain curve, of about $0.00008 \mathrm{~s}^{-1}$. The strain was calculated as the ratio between the displacement and the initial length of the fiber. All testings were conducted at ambient temperature $\left(\sim 22{ }^{\circ} \mathrm{C}\right)$ and a relative humidity (RH) of about $60 \%$. In order to measure the cross-sectional area of the fibers, for each tested fiber, an adjacent piece of the fiber (immediately next to the one tested) was kept for future measurement using scanning electron microscopy (SEM). Tensile strength, maximum strain, modulus of elasticity, and toughness of the silk fiber threads were determined from the stress versus strain curves. Toughness was obtained according to previous work [19] based on the integration of the stress-strain curves.

\section{Scanning electron microscopy (SEM)}

The silk fiber thread microstructure was investigated using a SEM Hitachi TEM 3000. The microscope was operated under an accelerating voltage of $15 \mathrm{kV}$. A working distance of $3 \mathrm{~mm}$ was applied and tilt was set to $0^{\circ}$. A pre-coating with a thin layer of approximately $20 \mathrm{~nm}$ of gold was done to make the fiber conductive and suitable for analysis. The microstructure of the fibers, before and after fracture, was investigated using SEM following the procedure described elsewhere [20-22]. The obtained images were post-processed using ImageJ (National Institutes of Health, Bethesda, Maryland, USA.), a Javabased image processing program. A contour line was drawn to delineate the fiber cross-section and the area was computed. Moreover, the fracture surface of the silk fiber thread was observed in order to compare the differences in the failure pattern of the 
Table 2 Consumption of mulberry leaves (in dry mg, mean \pm standard deviation), by each silkworm caterpillar, from third to fifth instar and total, using aqueous solutions with Bordeaux mixture $(\mathrm{Bm})$ in three levels, water, and non-treated leaves

\begin{tabular}{lllll}
\hline Treatments & 3rd instar & 4th instar & 5th instar & Total \\
\hline Control & $78 \pm 3$ & $277 \pm 12$ & $2.852 \pm 264$ & $3.210 \pm 249 \mathrm{ab}^{1}$ \\
Water & $79 \pm 2$ & $280 \pm 6$ & $2.945 \pm 69$ & $3.305 \pm 67 \mathrm{a}$ \\
Bm 5\% & $78 \pm 4$ & $254 \pm 29$ & $2.775 \pm 128$ & $3.107 \pm 158 \mathrm{abc}$ \\
Bm 10\% & $79 \pm 2$ & $257 \pm 12$ & $2.552 \pm 18$ & $2.888 \pm 27 \mathrm{bc}$ \\
Bm 20\% & $71 \pm 4$ & $247 \pm 12$ & $2.468 \pm 30$ & $2.786 \pm 43 \mathrm{c}$ \\
\hline
\end{tabular}

${ }^{1}$ Average values followed by the same letters in the same column do not differ by Tukey test (5\%)

Table 3 Mortality of caterpillars, means, and standard deviation values of weight of fresh cocoons and cocoons shells and raw silk (RS) obtained from caterpillars fed with mulberry leaves enriched with aqueous solution of Bordeaux mixture $(\mathrm{Bm})$ in three levels $(5,10$, and $20 \%)$, with water and nontreated (control)

\begin{tabular}{lclll}
\hline Treatments & Mortality (\%) & Fresh cocoons $(\mathrm{g})$ & Cocoons shells $(\mathrm{g})$ & Raw silk (\%) \\
\hline Control & 6.5 & $1.23 \pm 0.16 \mathrm{~b}^{1}$ & $0.30 \pm 0.03 \mathrm{ab}$ & $25.3 \pm 3.1 \mathrm{a}$ \\
Water & 8.0 & $1.42 \pm 0.23 \mathrm{a}$ & $0.31 \pm 0.05 \mathrm{a}$ & $23.7 \pm 3.3 \mathrm{ab}$ \\
BM 5\% & 8.6 & $1.21 \pm 0.16 \mathrm{~b}$ & $0.29 \pm 0.04 \mathrm{ab}$ & $24.7 \pm 4.1 \mathrm{a}$ \\
BM 10\% & 9.8 & $1.22 \pm 0.18 \mathrm{~b}$ & $0.27 \pm 0.04 \mathrm{~b}$ & $23.9 \pm 3.8 \mathrm{ab}$ \\
BM 20\% & 11.7 & $1.21 \pm 0.17 \mathrm{~b}$ & $0.27 \pm 0.05 \mathrm{~b}$ & $21.0 \pm 2.9 \mathrm{~b}$
\end{tabular}

${ }^{1}$ Means followed by the same letters in the same column do not differ by Tukey test $(5 \%)$

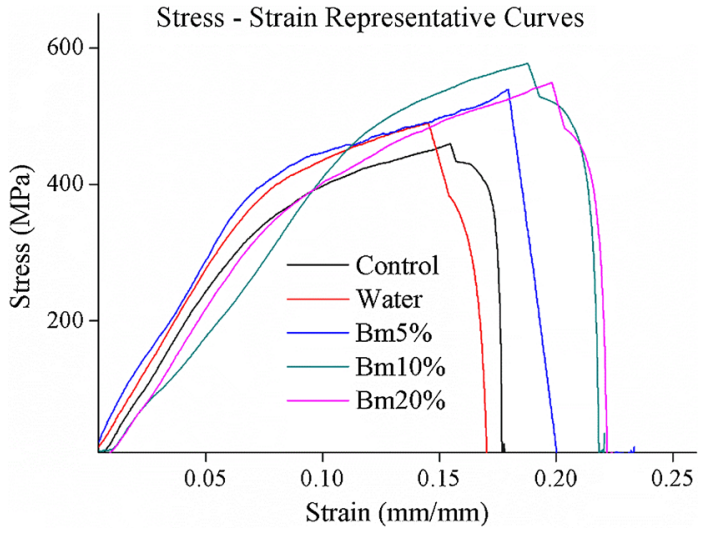

Figure 3 Typical stress versus strain curves of silk fiber threads produced by caterpillars fed with mulberry leaves enriched with aqueous solution of Bordeaux mixture $(\mathrm{Bm})$ in three concentrations $(5,10$ and $20 \%)$.

threads obtained from caterpillars fed with the experimental diets. Energy dispersive analyses were made through a dispersible microprobe for identification of the elements $(\mathrm{Cu}$ and $\mathrm{Ca})$ and qualitative analysis.

\section{X-ray diffraction (XRD)}

The X-ray diffraction (XRD) was performed on a XRD-6000 (Shimadzu, Japan). In order to proceed with the analysis, the silk fiber threads were placed between sheets of glass. Diffraction patterns of X-rays were obtained using a diffractometer with a Geiger counter. A diffracted intensity of radiation was measured in a $2 \theta$ range between $5^{\circ}$ and $40^{\circ}$ at a rate of $0.07^{\circ} / \mathrm{min}$ and using $\mathrm{CuK} \alpha$ radiation filtered in $\mathrm{Ni}$. The full width at half-maximum height (FWHM) of the diffraction peaks was used for calculating the crystallinity of the silk fibers by adjusting the data of X-ray diffraction with a GaussLorentz function.

\section{Results}

\section{Properties of the silk cocoons}

No statistical difference was observed in the amount of food ingested by caterpillars from different treatments on evaluations performed by instar. However, considering all the three instar together, we observed that the consumption was greater when the caterpillars were fed on mulberry leaves moistened with water in comparison to the diets with 10 and $20 \%$ of $\mathrm{Bm}$. The treatment of leaves with $5 \% \mathrm{Bm}$ aqueous solution did not affect caterpillars' consumption (see 
Table 4 Means and standard deviation values of tensile strength, maximum strain, and modulus of elasticity of silk fiber threads produced by caterpillars fed with mulberry leaves enriched with aqueous solution of Bordeaux mixture $(\mathrm{Bm})$ in three concentrations (5, 10, and 20\%)

\begin{tabular}{llllr}
\hline Treatments & Tensile strength $(\mathrm{MPa})$ & Maximum strain $(\mathrm{mm} / \mathrm{mm})$ & Modulus of elasticity $(\mathrm{GPa})$ & Toughness $\left(\mathrm{kJ} / \mathrm{m}^{3}\right)$ \\
\hline Control & $540 \pm 33 \mathrm{~b}^{1}$ & $0.15 \pm 0.07 \mathrm{~b}$ & $6.1 \pm 1.2 \mathrm{ab}$ & $919 \pm 314 \mathrm{a}$ \\
Water & $520 \pm 55 \mathrm{~b}$ & $0.17 \pm 0.04 \mathrm{~b}$ & $5.4 \pm 1.3 \mathrm{ab}$ & $906 \pm 395 \mathrm{a}$ \\
Bm 5\% & $605 \pm 60 \mathrm{ab}$ & $0.25 \pm 0.06 \mathrm{a}$ & $4.3 \pm 1.0 \mathrm{~b}$ & $1248 \pm 437 \mathrm{a}$ \\
Bm 10\% & $657 \pm 50 \mathrm{a}$ & $0.24 \pm 0.05 \mathrm{a}$ & $6.4 \pm 0.8 \mathrm{a}$ & $1142 \pm 537 \mathrm{a}$ \\
Bm 20\% & $632 \pm 29 \mathrm{a}$ & $0.25 \pm 0.09 \mathrm{a}$ & $4.5 \pm 0.8 \mathrm{~b}$ & $1215 \pm 333 \mathrm{a}$ \\
\hline
\end{tabular}

${ }^{1}$ Means followed by the same letters in the same column do not differ by Tukey test $(5 \%)$
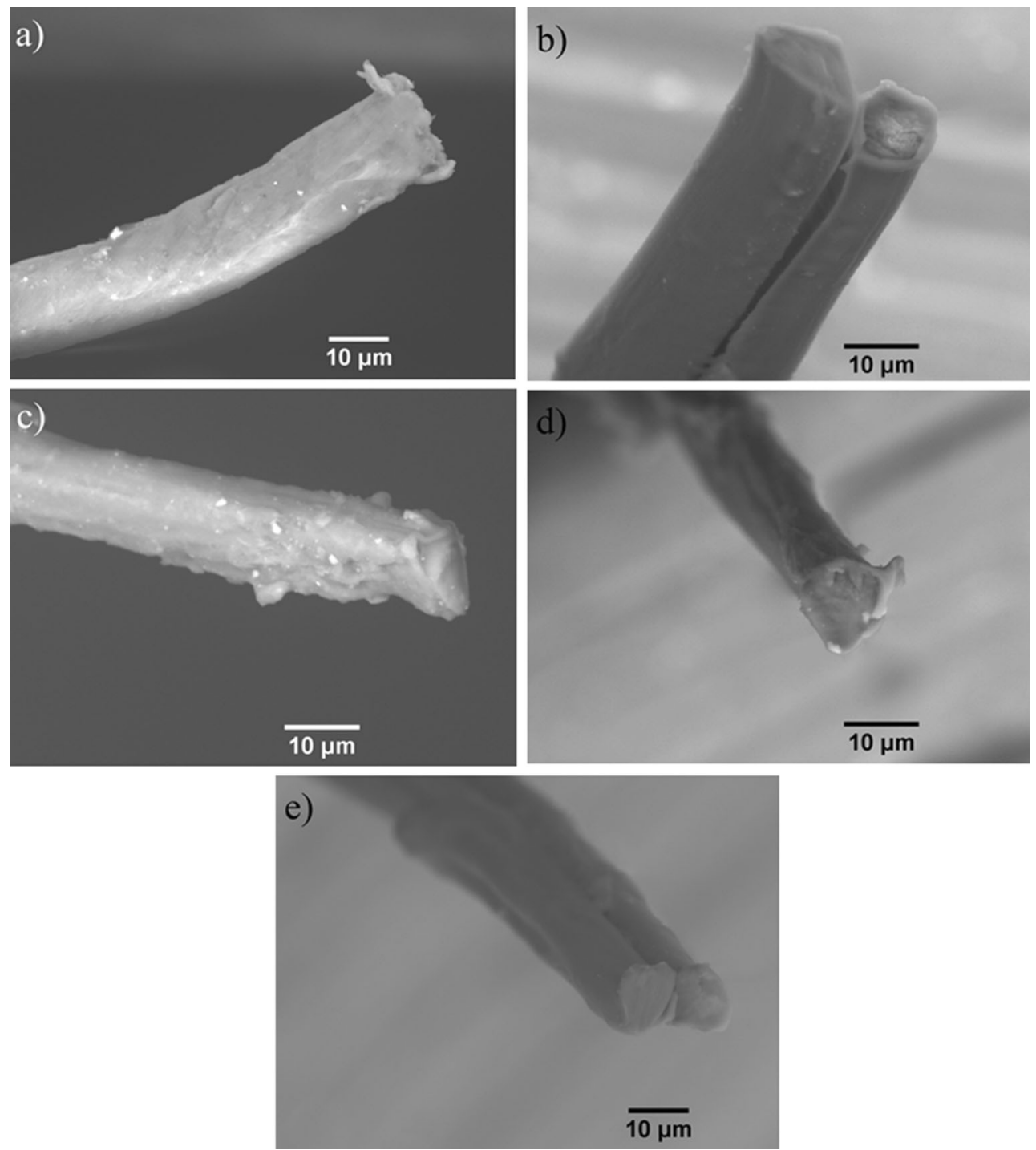

Figure 4 Scanning electron microscopy (SEM) micrographs of the fracture surface of silk fiber from caterpillar fed with mulberry leaves: a without treatment with Bordeaux mixture $(\mathrm{Bm})$; $\mathbf{b}$ without

Table 2). On analyzing the diets in which Bm was introduced, it can be verified that the increase of $\mathrm{Bm}$ promotes a reduction in food consumption. treatment with Bm but moistened with water; c sprayed with $5 \%$ solution of $\mathrm{Bm}$; d sprayed with $10 \%$ solution of $\mathrm{Bm}$; e sprayed with $20 \%$ solution of $\mathrm{Bm}$.

The mortality rate of caterpillars was lower (6.5-8.0\%) when no Bm was introduced to the caterpillars' diet. The addition of Bm to the caterpillars' 
diet caused an dose-dependent increase on mortality rate, starting from 8.6 and reaching $11.7 \%$ (see Table 3).

The addition of the $\mathrm{Bm}$ did not influence the weight of fresh cocoons when compared to the control treatment. In this case, the best result was obtained for the caterpillars fed on mulberry leaves moistened with water, which also resulted on heavier shell cocoons in comparison with $\mathrm{Bm} 10$ and $20 \%$. There was no difference in the weights of the cocoon shells of caterpillars fed on mulberry leaves moistened with water, treated with aqueous solution with Bm 5\%, and non-treated leaves. Regarding the raw silk content, no differences were observed between control and the other treatments, with the exception of $\mathrm{Bm} 20 \%$, which negatively impacted the cocoon production (see Table 3).

\section{Mechanical behavior of the silk fiber}

The use of $\mathrm{Bm}$ at concentrations of 10 and $20 \%$ resulted in an increase, of 22 and $16 \%$, respectively, in the tensile strength of the silk fiber produced by caterpillars: $520 \pm 55 \mathrm{MPa}$ in the treatment with leaves sprayed with water (lowest value obtained in the tests) to $657 \pm 50 \mathrm{MPa}$ in the treatment with $10 \%$ $\mathrm{Bm}$ solution. Figure 3 presents the typical stress versus strain curves for each treatment showing the increase in the tensile behavior and maximum strain by adding Bm.

The maximum strain capacity of the silk fiber during the tensile test was greatly favored by the presence of $\mathrm{Bm}$ in the diet: an increase in the strain capacity of $60 \%$ is observed in the treatment of $\mathrm{Bm}$ at a concentration of $5 \%$ when compared to the silk fiber threads produced by caterpillars fed with only mulberry leaves. There was no significant difference among other treatments (see Table 4). Higher values of strength and larger strain levels are the ideal conditions leading to greater ductility of the silk fiber, i.e., greater ability to resist to tensile without drastic rupture. Nevertheless, despite higher values for Bm treatments, no significant differences were observed for toughness of the silk fiber threads. Additionally, the inclusion of $\mathrm{Bm}$ did not increase modulus of elasticity of the threads. The $10 \%$ solution led to higher modulus of elasticity in relation to the other concentration.
Table 5 Means and standard deviation values of $\mathrm{Ca}$ and $\mathrm{Cu}$ concentration in the different treatments, Spearman's correlation coefficient $(r)$, and $p$ value

\begin{tabular}{lll}
\hline Treatments & $\mathrm{Ca}(\%$ mass $)$ & $\mathrm{Cu}$ (\% mass) \\
\hline Control & $0.5 \pm 0.2$ & $2.6 \pm 0.0$ \\
Water & $0.9 \pm 0.4$ & $2.3 \pm 0.5$ \\
Bm 5\% & $0.6 \pm 0.1$ & $2.6 \pm 0.1$ \\
Bm 10\% & $0.6 \pm 0.3$ & $3.0 \pm 0.5$ \\
Bm 20\% & $0.6 \pm 0.0$ & $3.7 \pm 1.6$ \\
$\mathrm{r}$ & -0.29 & 0.83 \\
$p$ & $>0.20$ & $=0.0003$ \\
\hline
\end{tabular}

Values obtained by EDX in the silk fiber threads samples during SEM observations

\section{Microstructure characterization}

SEM micrographs of the fracture surface of silk thread show a change in their patterns during different treatments. It was more homogeneous (rupture of two fibroins in the same filament length) as the concentration of Bm increased. In the treatment using only mulberry leaves (without enrichment with Bm and water), the two-fibroin filament broke in different lengths during the test. As the Bm concentration increases, the rupture of the silk fibers in different lengths is less apparent, disappearing at a Bm concentration of $20 \%$. The pattern of disruption is an indication that the presence of $\mathrm{Bm}$ has increased the cohesion between the two-fibroin filaments that form the silk thread, making it more resistant to tensile loads and allowing greater deformation before the rupture of the silk fiber thread takes place (see Fig. 4).

An increase in the concentration of $\mathrm{Ca}$ in the silk fiber threads treated with $\mathrm{Bm}$ was observed. As expected, an increased concentration of $\mathrm{Cu}$ in the treatment with 10 and $20 \%$ of $\mathrm{Bm}$ is also noted (Table 5). These results can be the causes of the observed differences in the mechanical performance and structural changes (crystallinity) of the evaluated silk fiber threads. The $\mathrm{Cu}$ and $\mathrm{Ca}$ ions have been reported in the literature $[23,24]$ as being responsible for the agglomeration of fibroin chains in silk fiber threads.

\section{X-ray diffraction}

The X-ray diffractograms of silk fiber threads in different conditions and the calculated results of crystallinity are presented in Fig. 5 and Table 6, 


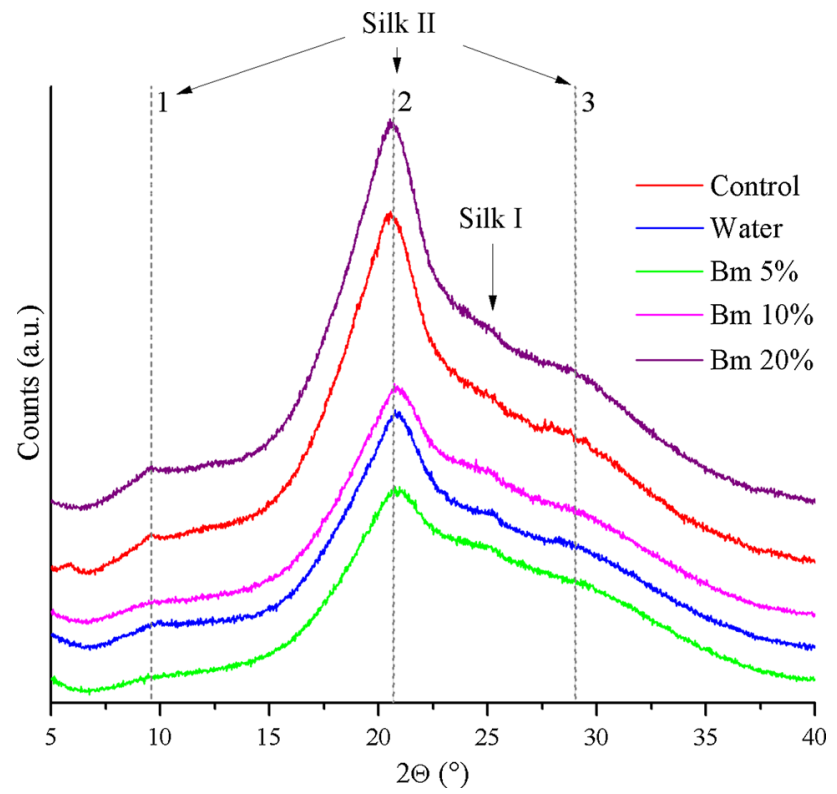

Figure 5 X-ray diffractograms of silk fiber thread produced in different conditions. Peaks 1, 2, and 3 are related to Silk II, while the smooth peak between peaks 2 and 3 corresponds to Silk I.

respectively. The three peaks denoted in Fig. 5 represent Silk II, whereas the smooth peak located between peaks two and three corresponds to Silk I. No difference regarding Silk I was observed between the treatments. Silk I is in a glandular state prior to crystallization and is easily converted to Silk II, which consists of beta-sheet secondary structure, in the spinning process [25]. The results show increased crystallinity of the silk fiber threads when the food is enriched with water and with Bm (mainly on the concentration of $10 \%$ ), as well as the interplanar spacing on peak 1 (Table 6). No relevant differences were observed in the crystal size of the different treatments. With the highest concentration of $\mathrm{Bm}$ $(20 \%)$, the crystallinity values are similar to the control condition. The higher crystallinity can be the result of changes in the flow of silk secretion caused by metal ions (ions of $\mathrm{Ca}$ and $\mathrm{Cu}$, for example) present in the water and in the $\mathrm{Bm}$ that modify the rheology of the silk proteins, as reported in literature $[23,24]$. As observed in Table 5, there was an increased concentration of $\mathrm{Ca}$ and $\mathrm{Cu}$ in the treatments with Bm. Researchers [24] also reported the largest agglomeration of silk fibroin compounds with the highest concentration of $\mathrm{Ca}$, and it was shown that the fibroin macromolecular chains form complex with $\mathrm{Cu}$ ions, leading to more crystalline beta-type (beta-sheets) planes on the structure of silk fiber thread [13]. Similar results were reported using $\mathrm{TiO}_{2}$ nanoparticles [15]. High additive amount is likely to exceed the absorbing capacity of the silkworms, and the agglomeration of nanoparticles at a high concentration may make the interaction between the metals and the silk fibroin difficult. According to these authors [15], $\mathrm{TiO}_{2}$ nanoparticles interacted with the protein molecules and restricted the movement of protein molecules during secretion, then it was difficult to increase the nucleation sites of crystallization for silk fibroin around $\mathrm{TiO}_{2}$ nanoparticles.
Table 6 Crystallinity parameters determined from the X-ray diffractograms of silk fiber in different conditions

\begin{tabular}{|c|c|c|c|c|}
\hline Treatment & Crystallinity (\%) & Peak & Interplanar distance $(\AA)$ & Crystal size (nm) \\
\hline \multirow[t]{3}{*}{ Control } & \multirow[t]{3}{*}{78} & 1 & 8 & 2.0 \\
\hline & & 2 & 4 & 3.0 \\
\hline & & 3 & 3 & 1.0 \\
\hline \multirow[t]{3}{*}{ Water } & \multirow[t]{3}{*}{85} & 1 & 9 & 2.0 \\
\hline & & 2 & 4 & 3.0 \\
\hline & & 3 & 3 & 0.7 \\
\hline \multirow[t]{3}{*}{$\mathrm{Bm} 5 \%$} & \multirow[t]{3}{*}{85} & 1 & 9 & 2.0 \\
\hline & & 2 & 4 & 3.0 \\
\hline & & 3 & 3 & 0.8 \\
\hline \multirow[t]{3}{*}{$\mathrm{Bm} \mathrm{10 \%}$} & \multirow[t]{3}{*}{86} & 1 & 9 & 2.0 \\
\hline & & 2 & 4 & 3.0 \\
\hline & & 3 & 3 & 1.0 \\
\hline \multirow[t]{3}{*}{ Bm 20\% } & \multirow[t]{3}{*}{80} & 1 & 9 & 2.0 \\
\hline & & 2 & 4 & 3.0 \\
\hline & & 3 & 3 & 1.0 \\
\hline
\end{tabular}




\section{Conclusion}

The inclusion of aqueous solution with Bordeaux mixture $(\mathrm{Bm})$ in silkworms diet impaired cocoon production by causing a dose-dependent increase in mortality ratio that was up to 1.8 times higher than control. For the cocoons obtained, no difference was observed between Bm treatments and control, regarding the weight of fresh cocoons, cocoons shells, and raw silk. The consumption of leaves was negatively affected by the amount of $\mathrm{Bm}$ in the silkworms diet. The tensile strength and maximum strain of the silk fiber threads were greatly improved by the presence of $\mathrm{Bm}$ in the diet. Maximum strain increased around $60 \%$ with the use of Bm at a concentration of 5\%, when compared to the silk fiber threads produced by the caterpillars fed only with mulberry leaves. There was no significant difference among other treatments. No significant differences were observed for toughness of the silk fiber threads. There was an increase in the concentration of $\mathrm{Cu}$ in the silk fiber threads treated with Bm. The higher crystallinity can be the result of changes in the flow of silk secretion caused by metal ions (ions of $\mathrm{Ca}^{+}$and $\mathrm{Cu}^{+}$, for example) present in the water and in the $\mathrm{Bm}$, which alters the rheology of the silk proteins. Cocoon producers can be interested about using Bm on caterpillars feeding for the increase in cocoon quality, despite the increase in caterpillars mortality.

\section{Acknowledgements}

The authors would like to thank Coordenação de Aperfeiçoamento de Pessoal de Nível Superior (CAPES), Conselho Nacional de Desenvolvimento Científico e Tecnológico (CNPq) Fundação de Amparo à Pesquisa do Estado de São Paulo (FAPESP_process $n^{\circ}$ 12/24430-1) and Fundação de Amparo à Pesquisa do Estado de Minas Gerais (FAPEMIG).

\section{References}

[1] Sabbag OJ, Nicodemo D, Oliveira JEM (2013) Custos e viabilidade econômica da produção de casulos do bicho-daseda. Pesquisa Agropecuária Trop 43:187-194

[2] Takahashi R, Takahashi KM, Takahashi LS (2009) Sericicultura: uma promissora exploracão agropecuária. Funep, Jaboticabal

[3] Singh A et al (2015) Sericulture helpline series. Bionano Frontier, Mumbai
[4] Lawrence B et al (2008) Processing methods to control silk fibroin film biomaterial features. J Mater Sci 43(21): 6967-6985. doi:10.1007/s10853-008-2961-y

[5] Kameda T, Hashimoto T, Tamada Y (2011) Effects of supercooling and organic solvent on the formation of a silk sponge with porous 3-D structure, and its dynamical and structural characterization using solid-state NMR. J Mater Sci 46(24):7923-7930. doi:10.1007/s10853-0115925-6

[6] Zhang Y-C et al (2012) Conductive network formation during annealing of an oriented polyethylene-based composite. J Mater Sci 47(8):3713-3719. doi:10.1007/s10853011-6220-2

[7] Purohit KM, Kumar P (1996) Influence of various agronomical practices in India on the leaf quality in mulberry, a review. Sericologia 36:27-41

[8] Okamoto F, Rodella RA (2006) Características morfoanatômicas e bromatológicas de folhas de amoreira em relação às preferências do bicho-da-seda. Pesquisa Agropecuária Brasileira 41:195-203

[9] Taniai $\mathrm{K}$ et al (2014) Starvation-responsive glycine-rich protein gene in the silkworm Bombyx mori. J Comp Physiol 184(7):827-834

[10] Takano K, Arai N (1978) Studies on food value on the bases of feeding and cocoon productivity in the silkworm, Bombyx mori the amount of food intake and cocoon productivity. J Seric Sci Jpn 47(2):134-142

[11] Ki C, Park Y (2013) Effect of sericin blending on molecular orientation of regenerated silk fiber. Fibers Polym 14(9):1460-1467

[12] Perea GB et al (2013) The variability and interdependence of spider viscid line tensile properties. J Exp Biol 216(24):4722-4728

[13] Zhou L et al (2003) Copper in the silk formation process of Bombyx mori silkworm. FEBS Lett 554(3):337-341

[14] Vollrath F, Knight DP (2001) Liquid crystalline spinning of spider silk. Nature 410(29):541-548

[15] Cai L et al (2015) Reinforced and ultraviolet resistant silks from silkworms fed with titanium dioxide nanoparticles. ACS Sustain Chem Eng 3:2551-2557

[16] Peruch LAM, Bruna ED (2008) Relação entre doses de calda bordalesa e de fosfito potássico na intensidade do míldio e na produtividade da videira cv. 'Goethe'. Ciência Rural 38:2413-2418

[17] Polycarpo GV et al (2012) Enriquecimento da dieta do bicho-da-seda com extrato hidrossolúvel de soja. Ciência Rural 42(9):1669-1774

[18] International, A. (2014) Standard test method for tensile strength and young's modulus of fibers. ASTM International, West Conshohocken 
[19] Tonoli GDH et al (2011) Hybrid reinforcement of sisal and polypropylene fibers in cement-based composites. J Mater Civ Eng 23:177-187

[20] Milanese AC, Cioffi MOH, Voorwald HJC (2011) Mechanical behavior of natural fiber composites. Proc Eng 10:2022-2027

[21] Silva FDA, Chawla N, de Toledo Filho RD (2009) An experimental investigation of the fatigue behavior of sisal fibers. Mater Sci Eng 516(1-2):90-95

[22] Silva FDA, Chawla N, de Toledo Filho RD (2008) Tensile behavior of high performance natural (sisal) fibers. Comp Sci Technol 68(15-16):3438-3443
[23] Chen $X$ et al (2002) Conformation transition in silk protein films monitored by time-resolved fourier transform infrared spectroscopy: effect of potassium ions on nephila spidroin films. Biochemistry 50(41):1944-1950

[24] Sappington TW, Oishi K, Raikhel AS (2002) Structural characteristics of insect vitellogenins. In: Raikhel AS, Sappington TW (eds) Reproductive biology of invertebrates: progress in vitellogenesis. Science Publishers, Enfield

[25] Vepari C, Kaplan DL (2007) Silk as a biomaterial. Prog Polym Sci 32(89):991-1007 